\title{
Correspondence
}

\author{
Letters to the Editor should not exceed 500 words.
}

Ethics and Abortion. Sir Dugald Baird, F.R.C.o.G.; J. P. Crawford, M.D.; R. S.
Ferguson,

Implementing the Abortion Act. $\mathrm{H}$. A Robinson, M.B.................................173

Prescription Charges and Tuberculosis. W. D. Gray, M.B.; E. L. Feinmann, M.R.C.P. 174 Vocational Training for General Practice. B. Taylor, M.B. .............................174

"Normal" Temperature. W. F. M. Wallace, M.D. ............... W. Wh

Price of Blood. A. J. Zuckerman, M.D.......174

Railwaymen and Drug Side-effects. J. S Grant, F.R.C.S.ED. ..........................175

Factor IX Levels and Oestrogens. Aileen $M$ Dickins, F.R.C.O.G............................175

Slimming and Sleep. J. T. Silverstone

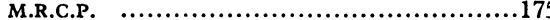

Brand Names. T. H. S. Burns, F.F.A.R.C.s...175
Long-term Corticosteroid Treatment of Asthma. I. Gregg, B.M.....................175

Deaths from Asthma. H. A. W. Forbes, D.M. 176 Pelvic Examination. J. A. McGarry, M.R.C.o.G. .................................176

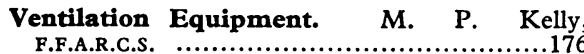
Measuring Blood-flow in Dialysis. R. $M$ Jameson, F.R.C.S.............................176 Oral Lichen Planus and Betamethasone. R. A. Cawson, M.B., F.D.S ......................176 Restrictions on Doctor in South Africa. L. H. Diamond, M.B......................177 Missing Loop. J. Breeze, M.R.C.o.G.; W. G. Mills, F.R.C.o.G. ...............................177 High-dosage Fluphenazine. P. W. Richmond, M.R.C.P., D.P.M. ...........................178 Basilar Syndrome. J. H. Cyriax, M.D.........178 Screening Tests for Phenylketonuria. S. F Cahalane, M.B. ............................178
Lower Limb Injuries. N. Roberts, F.R.C.S....178 Human Heart Transplantation. E. J. Schulz, M.B.

Hypermobile Joints. P. H. Beighton, M.R.C.P.ED., and F. T. Horan, F.R.C.S....................179 Injury from Liquid Propane. H. J. Fenn, M.R.C.s. ......................................179 Volvulus of the Sigmoid Colon in Africa. S. P. Bohrer, M.D. ........................179 Panhypopituitarism after Cured Tuberculous Meningitis. J. A. M. Frederiks, M.D. 179

Overseas Service. D. C. Ingledew, B.M. ......179 Medical Charities Appeal. H. Dodd, F.R.C.S.180 Group Practice Payments. R. L. Luffing ham, D.I.H. ................................180

Health Centres. Margaret O. Thorpe, M.D....180 Prescription Charges. J. Cantlie, M.B. ......180 Doctors on the Box. W. Rhys-Jones, D.P.H....180

\section{Ethics and Abortion}

SIR,-I think it most unfortunate that your leading article, Ethics and Abortion (6 April, p. 3), should use such an extravagant and emotionally charged phrase as " sinister echo of something that ended 20 years ago at Nuremberg " in relation to the recent Abortion Act.

What the Act does is to make clear beyond doubt that termination of pregnancy is legal and that the decision to terminate or not should be left, as far as possible, to the clinical judgement of the doctors concerned, and that in reaching their decision doctors may take into account the effect of the patient's total environment on her health. This is a recognition that a wide variety of environmental factors can have a serious effect on the health of the mother and of the whole family. A mother's concern and anxiety about the welfare of her children is one of the most important of these factors. A National Opinion Poll in $1967^{1}$ showed that $65 \%$ of general practitioners favoured a new law at least as liberal as the present Act.

The persistent attempt to draw an artificial distinction between " social " and "medical" indications on the part of opponents of change is unrealistic. In my view change in ethical standards does not arise.-I am, etc., M.R.C. Medical Sociology
Research Unit,

DUgald BaIRd. Aberdeen.

\section{REFERENCE}

1 New Statesman, 20 October 1967.

SIR,-As a practising psychiatrist at present who has to face the various dilemmas and new problems in this field so admirably discussed by Sir Roger Ormrod (6 April, p. 7) may I comment on your leading article ? (p. 3). Surely a decision by Parliament in a democracy cannot be described as sinister "superior orders" echoing Nuremberg 20 years ago (or rather what ended there and then). The boot could be argued to be on the other foot-namely, that doctors are prepared to dictate to the nation. I believe the real trouble in all this conflict is our profession's failure to accept psychological factors as respectable and real. Dr. Richard Hunter's personal view (p. 46) describes this state of affairs, but even some of Sir Roger Ormrod's supposed "non-therapeutic" situations would seem to many psychiatrists to have at least overtones in mental health.-I am, etc.,

$$
\text { Dartford, Kent. J. P. CRAWFORD. }
$$

* * It was a plea of "superior orders" in justification of a profession changing an ethical rule which we said would be the "sinister echo" not the superior orders themselves (in this case the provisions of the Abortion Act). -ED., B.M.f.

SIR,-The word ethics is apparently capable of a number of different interpretations. Your leader writer (6 April, p. 3) uses the arresting phrase, "Medical ethics are the collective conscience of the profession." A generalization of this order makes it obligatory for the profession (B.M.A. ?) to state its moral standpoint. To which school of moral philosophy does it adhere? Utilitarianism? Hedonism? Empiricism ? It cannot invoke some absolute authority behind its ethical rules, some theistic concept, for this would be arrogant usurpation of a religious function, and religion will have to be acknowledged to have precedence in rulegiving when it comes to matters of absolute authority.

The sinister echo of "superior orders" from Nuremberg over 20 years ago is admittedly far more chilling than the present echo from Tavistock House, but it is essentially the same echo. It will be interesting to learn, when the Representative Body takes its decisions, whether this "official" medical ethics will concede the right, sometimes even the duty, of the convinced dissenter to adopt the stand of conscientious objector. Or will the moral empire be essentially totalitarian in nature ?-I am, etc.,

\section{R. S. Ferguson}

Department of Sociology,
University of Salford,

Lancs.

\section{Implementing the Abortion Act}

SIR,-The Medical Defence Union (23 March, p. 759) is making the same mistake that the sponsors of the Abortion Act, 1967, have made in imagining that the ideal in theory will work the same way in practice. It is stated that practitioners interpreting the Act in good faith are unlikely to become involved in medico-legal complications. Later, however, it is stated the practitioner might have an action brought against him by a mother whose health had been injured by the continuance of pregnancy. Could this mean that if an inadequate mother has a nervous breakdown, be it immediately after or even months after, an unwanted child is born, the doctor might be faced with litigation?

The weakness of this Act is its vagueness. It is its sponsors who suffer from the misconception that it is not abortion on social grounds. The greatest number of controversial cases will come under the heading of Section 1 (1) (a) (4 November 1967, p. 303), in which abortion may be carried out if " the continuance of pregnancy would involve risk ... of injury to the physical or mental health of the pregnant woman ... greater than if the pregnancy were terminated." Surely the word "grave" should have been inserted before " risk of injury." Every case of pregnancy carried to its natural conclusion surely carries more risk and strain on the mother than if it is terminated early on. This vague condition, omitting as it does the word "grave," opens the floodgates to abortion by demand. To help the unfortunate woman with more children than she can cope with, the genuine case of physical illness, or psychiatric illness, the raped, the case of 